\title{
Therapeutic utility of natural estrogen receptor beta agonists on ovarian cancer
}

\author{
Jinyou Liu ${ }^{1,5}$, Suryavathi Viswanadhapalli ${ }^{1}$, Lauren Garcia ${ }^{1}$, Mei Zhou ${ }^{1,6}$, Binoj C. \\ Nair ${ }^{1}$, Edward Kost ${ }^{1}$, Rajeshwar Rao Tekmal' ${ }^{1}$ Rong Li $^{2}$, Manjeet K. Rao ${ }^{3}$, Tyler \\ Curiel $^{4}$, Ratna K. Vadlamudi ${ }^{1}$ and Gangadhara R. Sareddy ${ }^{1}$ \\ ${ }^{1}$ Department of Obstetrics and Gynecology, Cancer Therapy and Research Center, University of Texas Health Science Center, \\ San Antonio, Texas, USA \\ ${ }^{2}$ Department of Molecular Medicine, University of Texas Health Science Center, San Antonio, Texas, USA \\ ${ }^{3}$ Department of Cell Systems and Anatomy, University of Texas Health Science Center, San Antonio, Texas, USA \\ ${ }^{4}$ Department of Medicine, University of Texas Health Science Center, San Antonio, Texas, USA \\ ${ }^{5}$ Department of Oncology, Xiangya School of Medicine, Central South University, Hunan, P.R. China \\ ${ }^{6}$ Department of Gastroenterology, Second Xiangya Hospital and Xiangya School of Medicine, Central South University, \\ Hunan, P.R. China \\ Correspondence to: Gangadhara R. Sareddy, email: sareddy@uthscsa.edu \\ Ratna K. Vadlamudi, email: vadlamudi@uthscsa.edu
}

Keywords: ovarian cancer, natural ERß agonists, NF- $k B$

Received: February 07, $2017 \quad$ Accepted: April 28, $2017 \quad$ Published: June 12, 2017

Copyright: Liu et al. This is an open-access article distributed under the terms of the Creative Commons Attribution License 3.0 (CC BY 3.0), which permits unrestricted use, distribution, and reproduction in any medium, provided the original author and source are credited.

\section{ABSTRACT}

Ovarian cancer is the deadliest of all gynecologic cancers. Despite success with initial chemotherapy, the majority of patients relapse with an incurable disease. Development of chemotherapy resistance is a major factor for poor long-term survival in ovarian cancer. The biological effects of estrogens are mediated by estrogen receptor alpha $(E R \alpha)$ and estrogen receptor beta (ERß). Emerging evidence suggests that ovarian cancer cells express ER $\beta$ that functions as a tumor suppressor; however, the clinical utility of ERß agonists in ovarian cancer remains elusive. We tested the utility of two natural ERß agonists liquiritigenin (Liq), which is isolated from Glycyrrhiza uralensis and S-equol, which is isolated from soy isoflavone daidzein, for treating ovarian cancer. Both natural ERß ligands had significant growth inhibition in cell viability and survival assays, reduced migration and invasion, and promoted apoptosis. Further, ER $\beta$ agonists showed tumor suppressive functions in therapy-resistant ovarian cancer model cells and sensitized ovarian cancer cells to cisplatin and paclitaxel treatment. Global RNASeq analysis revealed that ERß agonists modulate several tumor suppressive pathways, including downregulation of the NF-кB pathway. Immunoprecipitation assays revealed that ER $\beta$ interacts with p65 subunit of NF-кB and ER overexpression reduced the expression of NF-кB target genes. In xenograft assays, ER $\beta$ agonists reduced tumor growth and promoted apoptosis. Collectively, our findings demonstrated that natural ER $\beta$ agonists have the potential to significantly inhibit ovarian cancer cell growth by anti-inflammatory and pro-apoptotic actions, and natural ER $\beta$ agonists represent novel therapeutic agents for the management of ovarian cancer.

\section{INTRODUCTION}

Ovarian cancer $(\mathrm{OCa})$ is the leading cause of death from gynecologic malignancies $[1,2]$. Due to the lack of early stage markers, advanced stage diagnosis of OCa is common and majority of patients will relapse with incurable disease despite therapy [3]. The lethality of OCa primarily stems from our inability to detect the disease at an early, organ-confined stage and also due to the lack of effective therapies for advanced disease $[4,5]$. Further, 
the molecular basis of this disease is not completely understood. This represents a significant problem in the management of patients with OCa and a critical need for the development of novel therapies treating OCa.

Estrogens are the main female sex steroid hormones that play a critical role in the proliferation and differentiation of ovary [6]. The biological effects of estrogens are mediated by estrogen receptor alpha $(\mathrm{ER} \alpha)$ and estrogen receptor beta $(\mathrm{ER} \beta)[7,8] . \mathrm{ER} \beta$ functions as a tissue-specific tumor suppressor with antiproliferative actions $[8,9]$. ER $\beta$ is a transcription factor that is implicated in the modulation of genes involved in multiple tumor suppression-related pathways. ER $\beta$ tumor suppression functions may be mediated by both ER $\beta$ :ER $\beta$ homodimer (that activate tumor suppressor functions) and ER $\beta: E R \alpha$ heterodimer (that blocks ER $\alpha$ oncogenic signaling) depending on the status of the cellular expression of ERs [10-12]. However, the molecular mechanism(s) through which ER $\beta$ mediates growth inhibition of OCa cells remains elusive.

Even though ER $\alpha$ and ER $\beta$ are structurally similar, their ligand-binding domains differ enough to be selective for different ligands [8, 13]. Recent studies identified liquiritigenin (Liq) [14] and S-equol as ER $\beta$ specific agonists $[15,16]$. Liq is isolated from the plant Glycyrrhiza uralensis and is a potent ER $\beta$ agonist; Liq exhibits a 20-fold higher affinity for $\operatorname{ER} \beta$ than for ER $\alpha$ [14]. S-equol is a compound that was isolated from the soy isoflavone daidzein via biotransformation [17]. S-equol has preferential binding to $\mathrm{ER} \beta$ ( $\mathrm{Ki}$ of $0.73 \mathrm{nM}$ for $\mathrm{ER} \beta$ compared to $\mathrm{Ki}$ of $6.41 \mathrm{nM}$ for $\mathrm{ER} \alpha$ ) and functions as an ER $\beta$ agonist $[17,18]$. Currently, Liq and S-equol are being tested to treat vasomotor symptoms (hot flashes) associated with menopause $[12,18]$. In Phase II clinical trials, Liq and S-equol were found to be safe and well tolerated and taken with high compliance.

In this study, we tested the significance and therapeutic potential of ER $\beta$ signaling in OCa progression using natural ER $\beta$ agonists as novel therapeutic agents. Using both in vitro and in vivo models, we demonstrated that natural ER $\beta$ agonists have tumor suppressive functions on OCa cells. Mechanistic studies showed that $\operatorname{ER} \beta$ agonists modulate several tumor inhibitory and inflammatory pathways, including attenuation of the NF- $\kappa \mathrm{B}$ pathway. Further, treatment with ER $\beta$ agonists reduced in vivo tumor growth and promoted apoptosis in a xenograft model.

\section{RESULTS}

\section{Natural ERß agonists reduced cell viability and survival and promoted apoptosis of $\mathrm{OCa}$ cells}

We examined whether activation of ER $\beta$ pathway by its natural agonists contribute to the reduction of cell viability and survival of OCa cells. SKOV3 and BG1 cells treated with S-equol or Liq exhibited a significant dose-dependent reduction in viability (Figure 1A, 1B). Further, treatment with S-equol and Liq also exhibited an inhibitory effect on the viability of therapy-resistant ES2 (cisplatin resistant) and SKOV3-TR (taxol resistant) cells (Figure 1A, 1B). These natural ER $\beta$ agonists significantly reduced the colony formation ability of ES2 and SKOV3 cells (Figure 1C, 1D). To further confirm the effect of ER $\beta$ on cell proliferation, ES2 cells were transduced with ER $\beta$ expression vector. Overexpression of ER $\beta$ significantly reduced the proliferation of ES2 cells when compared to control cells (Figure 1E). We next examined whether ER $\beta$ agonists can induce apoptosis as measured by caspase 3/7 activity. As shown in Figure 1F, both S-equol and Liq significantly increased the caspase 3/7 activity in ES2, SKOV3 and SKOV3-TR cells. Collectively, these results suggest that natural ER $\beta$ agonists have the potential to reduce cell viability and survival and to promote apoptosis of OCa cells.

\section{ER $\beta$ agonist sensitized OCa cells to chemotherapeutic drugs}

The standard chemotherapy treatment for $\mathrm{OCa}$ patients include the platinum based therapy or combination of paclitaxel with a platinum based compounds. Emerging studies suggested that using a multi-targeted approach has an advantage over using a single agent for $\mathrm{OCa}$ therapy, and sensitizing agents that improve the efficacy of chemotherapy are beneficial $[19,20]$. Since, ER $\beta$ agonists reduce the cell viability of therapy sensitive and resistant cells, we next examined whether ER $\beta$ agonist sensitizes the OCa cells to standard of care chemotherapy. ES2 and SKOV3 cells were pre-treated with Liq followed by treatment with chemotherapeutic drugs cisplatin and paclitaxel. ER $\beta$ agonist Liq significantly sensitized OCa cells to paclitaxel and cisplatin treatment (Figure 2A, 2B).

\section{Natural ER $\beta$ agonists reduced migration and invasion of $\mathrm{OCa}$ cells}

Recent studies using overexpression of ER $\beta$ demonstrated that reintroduction of ER $\beta$ into epithelial ovarian cancer cells leads to reduced cell proliferation, improved survival of mice and decreased metastases [21]. To examine the effect of natural ER $\beta$ agonists in reducing the migration and invasion of OCa cells, we performed in vitro migration and invasion assays. Treatment with either S-equol or Liq resulted in significantly less migration for both the SKOV3 and ES2 cells than for vehicletreated cells (Figure 2C). Further, treatment with either S-equol or Liq also significantly reduced the ability of ES2 and SKOV3 cells to invade the matrigel (Figure 2D). Collectively, these results suggested that natural ER $\beta$ agonists have the potential to reduce migration and invasion of OCa cells. 

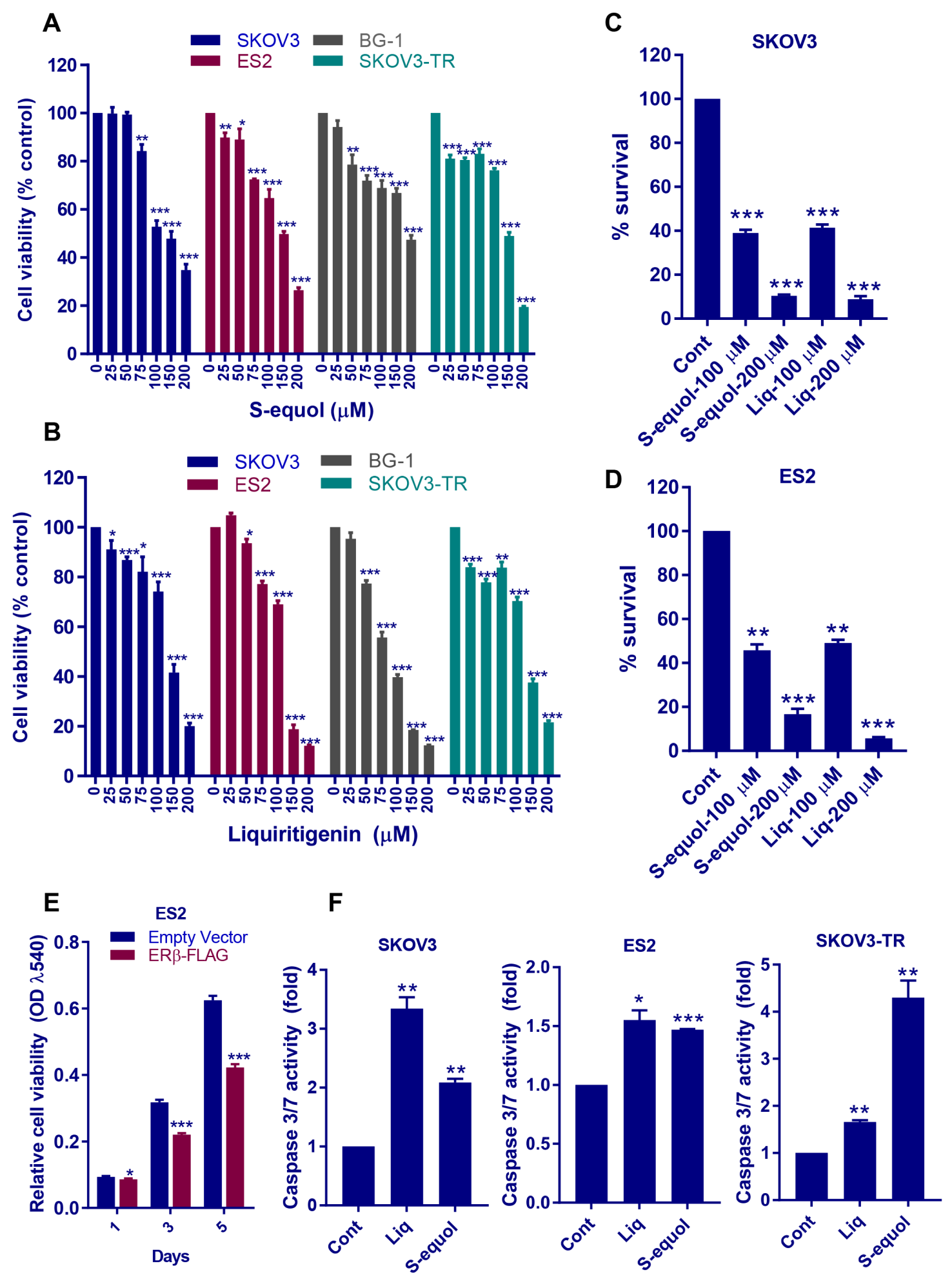

Figure 1: ERß agonists reduce OCa cell viability, survival and promote apoptosis in vitro. (A-B) ES2, BG-1, SKOV3, and SKOV3-TR cells were treated with vehicle or S-equol or Liq for $72 \mathrm{~h}$, and the cell viability was measured by using a MTT assay. (C-D) ES2 and SKOV3 cells were treated with vehicle, S-equol, or Liq for $72 \mathrm{~h}$ and then cultured in growth medium for additional 7 days. The number of colonies for each group was counted. (E) ES2 cells were transduced with either empty or ER $\beta$-FLAG expression vector and cell proliferation rates were measured using MTT assay. (F) ES2, SKOV3, and SKOV3-TR cells were treated with vehicle, S-equol, or Liq for $48 \mathrm{~h}$, and the Caspase- $3 / 7$ activity was measured as described in Methods. Data are represented as mean \pm SE. $* \mathrm{p}<0.05 ; * * \mathrm{p}<0.01 ; * * *$ $\mathrm{p}<0.001$. 
A

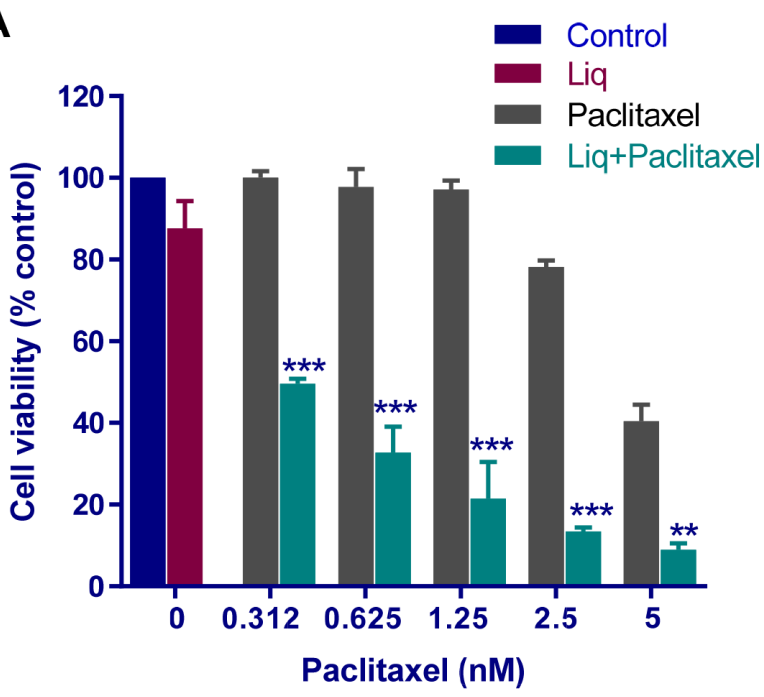

C
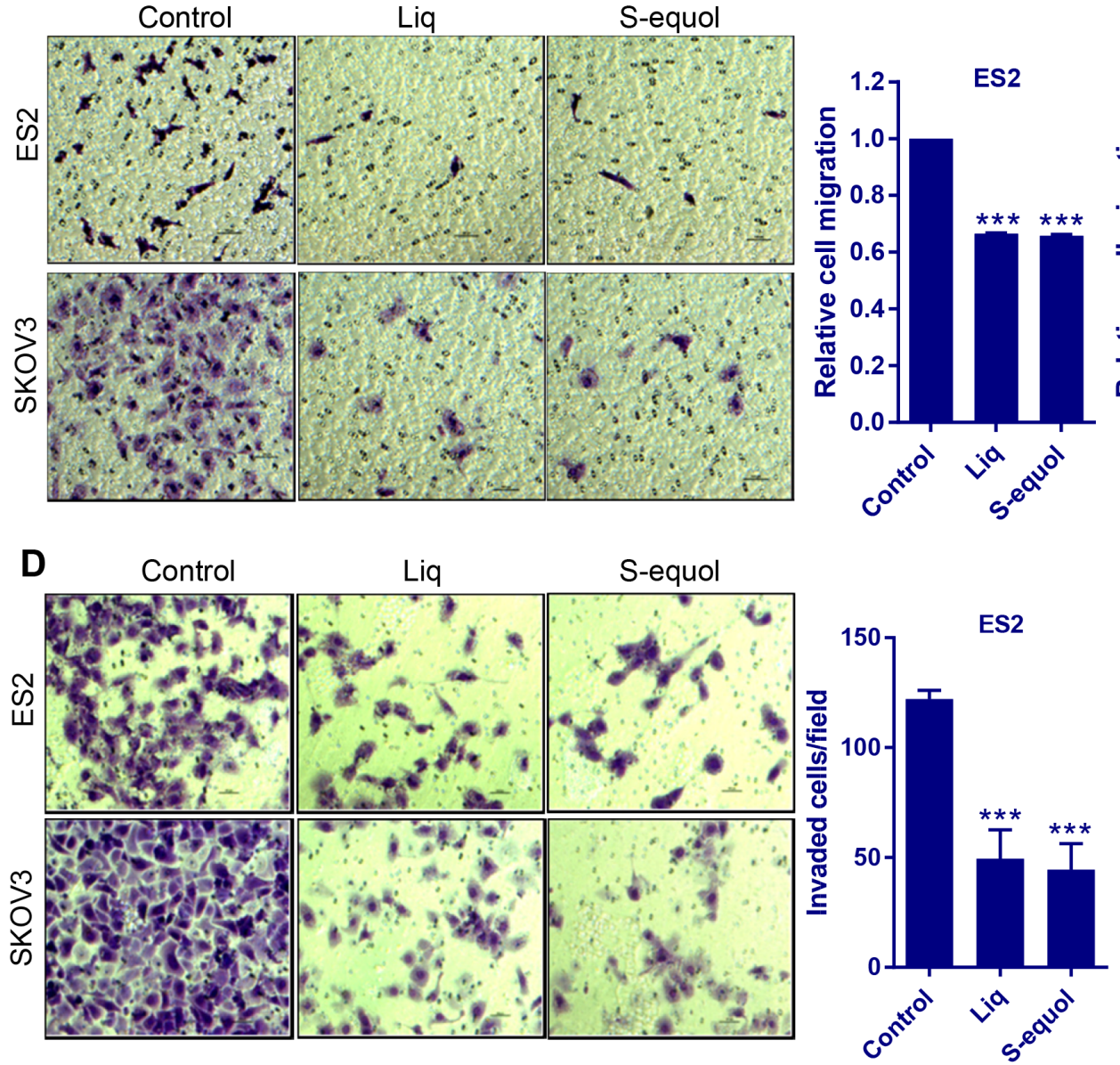
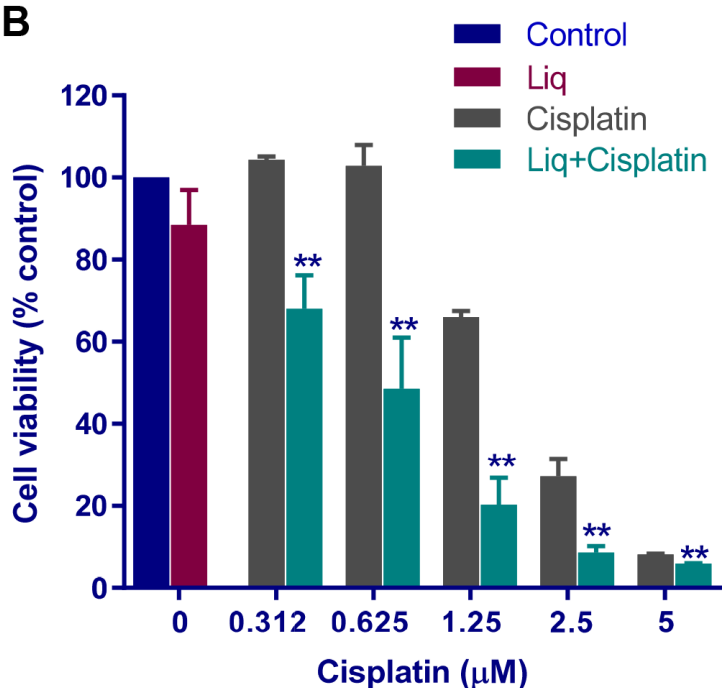

Cisplatin $(\mu \mathrm{M})$

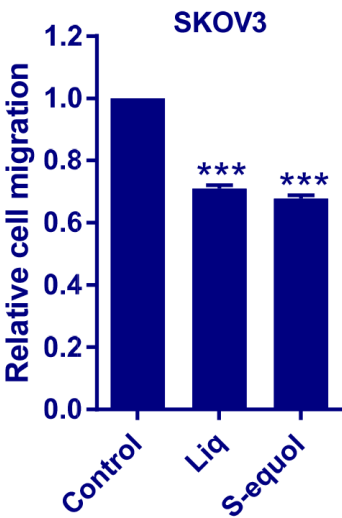

Figure 2: ERß agonists sensitize OCa cells to paclitaxel and cisplatin treatment and reduce migration and invasion of OCa cells. (A-B) ES2 cells were pretreated with Liq $(25 \mu \mathrm{M})$ for $48 \mathrm{~h}$ followed by treatment with varying doses of cytotoxic drugs paclitaxel or cisplatin for an additional 5 days. Cell viability was determined using MTT assay. (C) ES2 and SKOV3 cells were treated with vehicle, Liq or S-equol for $24 \mathrm{~h}$ and then used in transwell migration assays. Optical density was measured $16 \mathrm{~h}$ after migration. Photomicrographs of migrated cells in various treatments are shown. (D) Cell invasion potential of ES2 and SKOV3 cells treated with ER $\beta$ agonists was analyzed by using Matrigel invasion chamber assays. Photomicrographs of invaded cells in various treatments are shown. Data are represented as mean $\pm \mathrm{SE} .{ }^{* *} \mathrm{p}<0.01 ; * * * \mathrm{p}<0.001$. 


\section{Natural ERß agonists modulated expression of genes that contribute to tumor progression}

To understand the mechanisms by which natural ER $\beta$ agonists promote tumor suppression, we performed RNA sequencing to examine the gene expression changes modulated by Liq. ES2 cells were subjected to treatment with either vehicle or Liq for $24 \mathrm{~h}$. RNA was isolated and used for a global transcriptome analysis. Overall, 525 genes (1.5 fold change over control with $P<0.05)$ were differentially expressed in Liq-treated cells; 214 genes were downregulated and 311 genes were upregulated. A representative heat map of differentially expressed genes is shown in Figure 3A. The complete list is available in the GEO database under accession number GSE93807. The biological significance of the differentially expressed genes was determined using Ingenuity Pathway Analysis (IPA). IPA analysis revealed that Liq treatment significantly modulated the genes involved in inflammation, NRF2-mediated oxidative stress response, and MMP signaling (Figure 3B). Analysis of the molecular and cellular functions of these differentially expressed genes revealed that they are involved in cellular movement, cellular growth, proliferation, cell death and survival (Figure 3B). Further gene set enrichment analysis (GSEA) confirmed that the Liq-downregulated genes correlated well with signatures of inflammation, and NF$\kappa \mathrm{B}$ pathways (Figure $3 \mathrm{C}$ ). Using RT-qPCR analyses, we validated the expression of selected genes, including proinflammatory cytokines, MMPs, and adhesion molecules in ES2 and SKOV3 cells (Figure 3D).

\section{Natural ER $\beta$ agonists attenuated activation of $\mathrm{NF}-\kappa \mathrm{B}$ pathway in OCa cells}

$\mathrm{NF}-\kappa \mathrm{B}$ signaling plays a critical role in many steps of cancer initiation and progression and is a critical mediator of inflammatory responses [22]. Since RNA-seq data revealed that NF- $\mathrm{kB}$ and immune pathways are the top pathways modulated upon Liq treatment, we hypothesized that ER $\beta$ cross talk and inhibit activation of NF- $\mathrm{kB}$ via non-classical mechanisms. We treated cells with either S-equol or Liq and found that both agonists significantly reduced the NF- $\kappa \mathrm{B}-$ Luc reporter activity in ES2, SKOV3 and SKOV3-TR cells in a dose-dependent manner (Figure $4 \mathrm{~A})$. Further, we confirmed the downregulation of the NF-кB target genes IL-1 beta, CXCL8 and PTGS2 by S-equol and Liq in ES2 and SKOV3 cells (Figure 4B, $4 C)$. To demonstrate $E R \beta$ crosstalk with NF-кB pathway, we performed immunoprecipitation assays. GST pulldown assay using ER $\beta$-GST revealed that ER $\beta$ interacts with p65 subunit of NF-kB (Figure 4D). Further, we also confirmed the interaction of ER $\beta$ with p65 by performing immunoprecipitation assays using ER $\beta$ overexpressed cells (Figure 4E). Importantly, overexpression of ER $\beta$ significantly reduced the expression of NF- $\mathrm{kB}$ target genes in SKOV3 cells (Figure 4F). These results suggest that ER $\beta$ interacts with NF- $\kappa B$ complex and attenuates the activation of NF- $\mathrm{KB}$ pathway.

\section{Natural ERß agonist Liq reduced OCa tumor growth in vivo}

To complement in vitro studies, we tested the efficacy of the natural ER $\beta$ agonist Liq in vivo using OCa xenograft tumor model. SKOV3ip1-Luc cells were injected into the peritoneum of nude mice $(\mathrm{n}=5)$, and tumor growth was measured by using Xenogen in vivo imaging system. Liq treatment $(20 \mathrm{mg} / \mathrm{Kg} /$ day/Oral) significantly reduced tumor volume and tumor weight (Figure 5A5C). Further, mice treated with Liq also had significantly fewer tumor nodules than control mice (Figure 5D). Immunohistochemical analysis of tumor sections revealed that Liq treatment resulted in less expression of the proliferation marker Ki-67 in tumors compared to control (Figure 5E). Further, the effect of Liq on apoptosis was confirmed by TUNEL assay. As shown in Figure $5 \mathrm{~F}$, the number of TUNEL-positive apoptotic cells was significantly greater in Liq treated tumors than in control tumors. To further study the effect of ER $\beta$ agonist Liq on the expression of NF- $\mathrm{\kappa B}$ target genes, tumor sections were subjected to IHC analysis of IL-1 beta and Cox-2. As shown in Figure 5G, Liq treatment significantly reduced the expression of IL-1 beta and Cox-2 in tumors compared to vehicle treatment. Collectively, these results suggested that natural ER $\beta$ agonist significantly downregulated OCa progression in vivo and induced apoptosis.

\section{DISCUSSION}

Emerging evidence suggests that $E R \beta$ functions as a tissue-specific tumor suppressor with anti-proliferative actions [23-26]. Despite ER expression in 67\% of OCa, anti-estrogen therapy has had limited success, and the benefit of hormonal therapy has not been systematically studied [27]. ER $\beta$ expression is downregulated in many tumors including $\mathrm{OCa}[23,26,28-30]$. Loss of ER $\beta$ expression increases the risk for metastasis [31], and correlates with shorter overall survival and the lack of clinical response to chemotherapy in $\mathrm{OCa}$ [32]. Reintroduction of ER $\beta$ in OCa cells reduces their proliferation [21]. Even though emerging evidence suggests a tumor suppressor role of ER $\beta$ in OCa, the clinical utility of ER $\beta$ is limited because of the lack of mechanistic insights and agents that specifically target $\mathrm{ER} \beta$.

We examined whether targeting ER $\beta$ using naturally available agonists has utility for treating OCa. Both S-equol and Liq had tumor suppressive functions by reducing OCa cell viability, migration and invasion. Further S-equol and Liq also inhibited the growth of therapy-resistant OCa cells and sensitized OCa cells to 


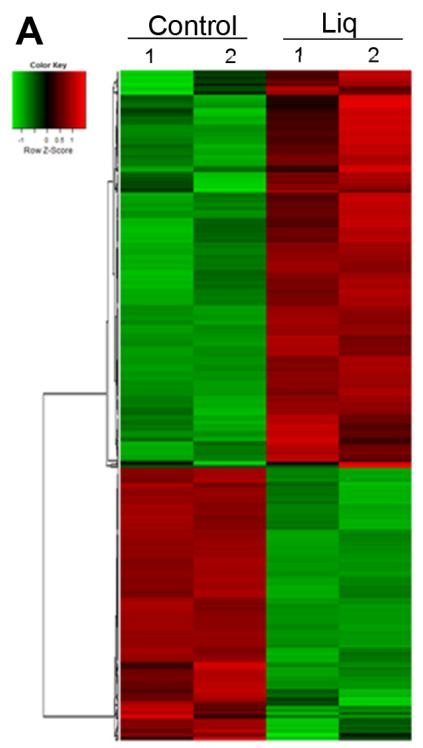

\section{B}

\begin{tabular}{|l|l|l|}
\hline Ingenuity Canonical Pathways & $-\log (\mathrm{p}$-value $)$ & Ratio \\
\hline Granulocyte Adhesion and Diapedesis & $6.42 \mathrm{E} 00$ & $9.6 \mathrm{E}-02$ \\
\hline Agranulocyte Adhesion and Diapedesis & $6.02 \mathrm{E} 00$ & $8.99 \mathrm{E}-02$ \\
\hline NRF2-mediated Oxidative Stress Response & $5.24 \mathrm{E} 00$ & $8.29 \mathrm{E}-02$ \\
\hline Inhibition of Matrix Metalloproteases & $4.72 \mathrm{E} 00$ & $1.79 \mathrm{E}-01$ \\
\hline Protein Kinase A Signaling & $2.6 \mathrm{E} 00$ & $4.62 \mathrm{E}-02$ \\
\hline Eicosanoid Signaling & $2.46 \mathrm{E} 00$ & $8.96 \mathrm{E}-02$ \\
\hline HIF1 Signaling & $2.42 \mathrm{E} 00$ & $6.96 \mathrm{E}-02$ \\
\hline IL-8 Signaling & $2.38 \mathrm{E} 00$ & $5.58 \mathrm{E}-02$ \\
\hline Tight Junction Signaling & $1.94 \mathrm{E} 00$ & $5.39 \mathrm{E}-02$ \\
\hline
\end{tabular}

\begin{tabular}{|l|c|l|}
\hline Molecular and Cellular Functions & p-value & \#Molecules \\
\hline Cellular Movement & $5.27 \mathrm{E}-05-2.98 \mathrm{E}-17$ & 146 \\
\hline Cellular Growth and Proliferation & $5.78 \mathrm{E}-05-7.04 \mathrm{E}-14$ & 203 \\
\hline Cellular Development & $5.78 \mathrm{E}-05-1.06 \mathrm{E}-12$ & 192 \\
\hline Cellular Function and Maintenance & $9.07 \mathrm{E}-06-1.25 \mathrm{E}-10$ & 136 \\
\hline Cell Death and Survival & $4.86 \mathrm{E}-05-1.30 \mathrm{E}-10$ & 175 \\
\hline
\end{tabular}

C
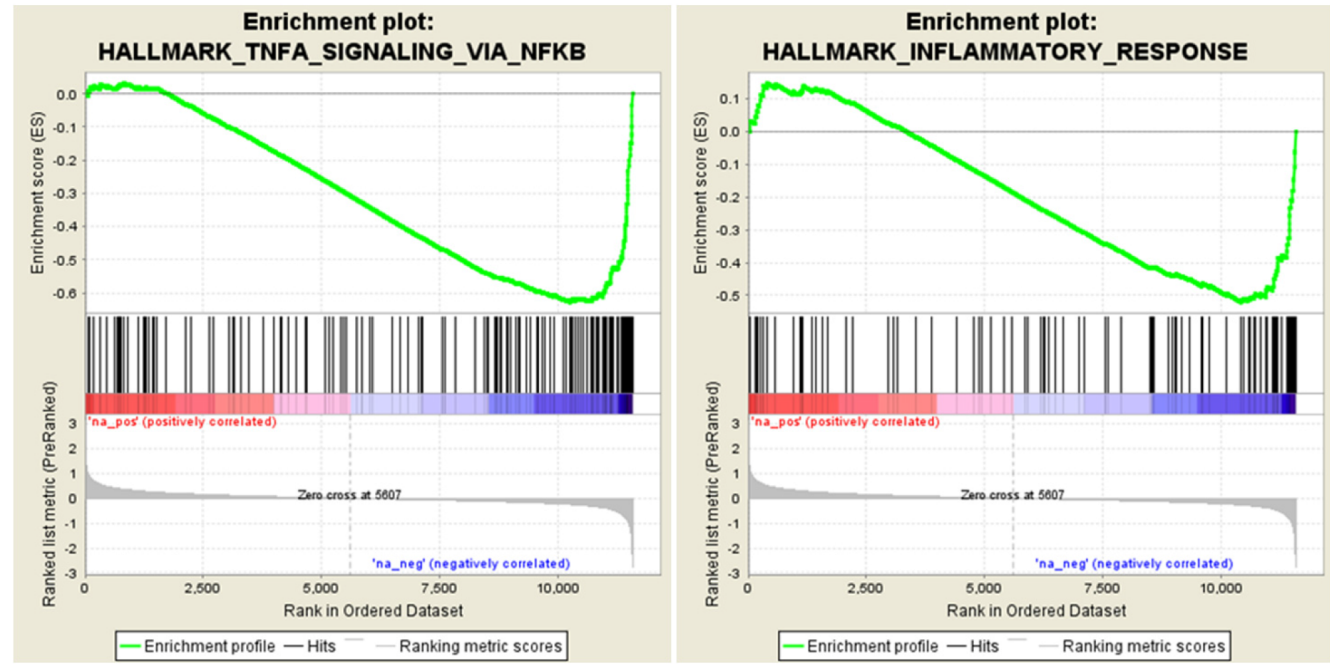

D
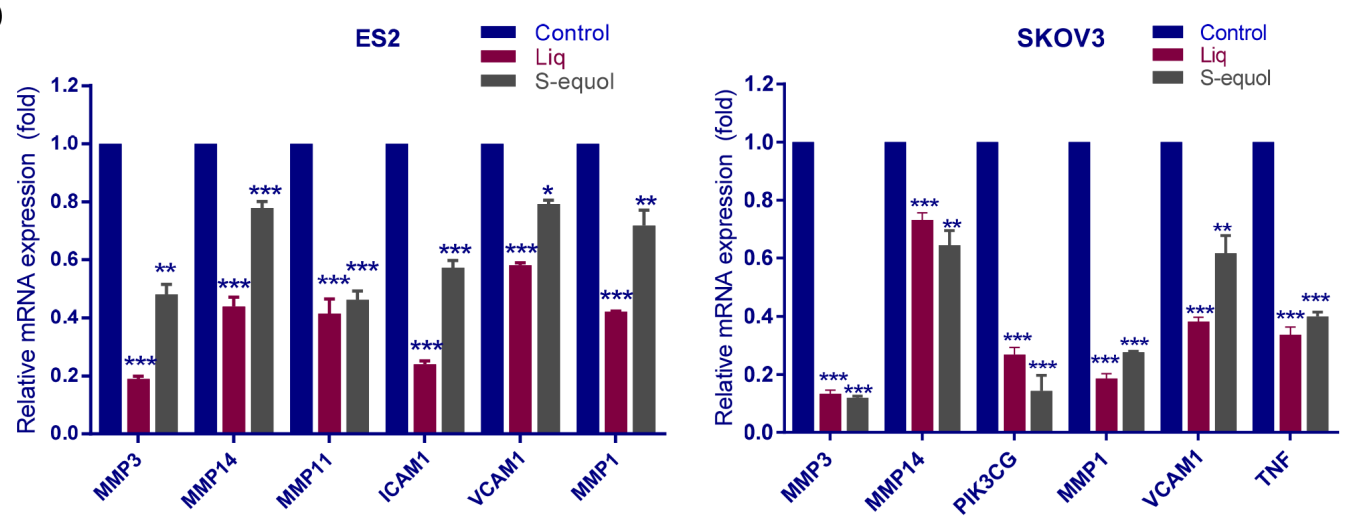

Figure 3: Analysis of global transcriptional changes modulated by ER $\beta$ agonists in OCa cells. Total RNA was isolated from the ES2 cells that were treated with either vehicle or Liq $(100 \mu \mathrm{M})$ for $24 \mathrm{~h}$ and subjected to RNA sequencing. (A) Heat map of differentially expressed genes between vehicle and Liq is shown. (B) Differentially expressed genes were subjected to pathway analysis using IPA software, and the selected top canonical pathways are shown. Analysis of molecular and cellular functions of differentially expressed genes are shown. (C) Gene set enrichment analysis (GSEA) testing correlation of Liq-regulated genes with signatures of NF- $\mathrm{kB}$ signaling gene set and inflammatory response gene set. (D) ES2 and SKOV3 cells were treated with either vehicle or Liq or S-equol for $24 \mathrm{~h}$, and the selective genes representing each pathway were validated by using RT-qPCR. Data are represented as mean $\pm \mathrm{SE}$. ${ }^{*} \mathrm{p}<0.05 ; * * \mathrm{p}<0.01 ; * * * \mathrm{p}<0.001$. 

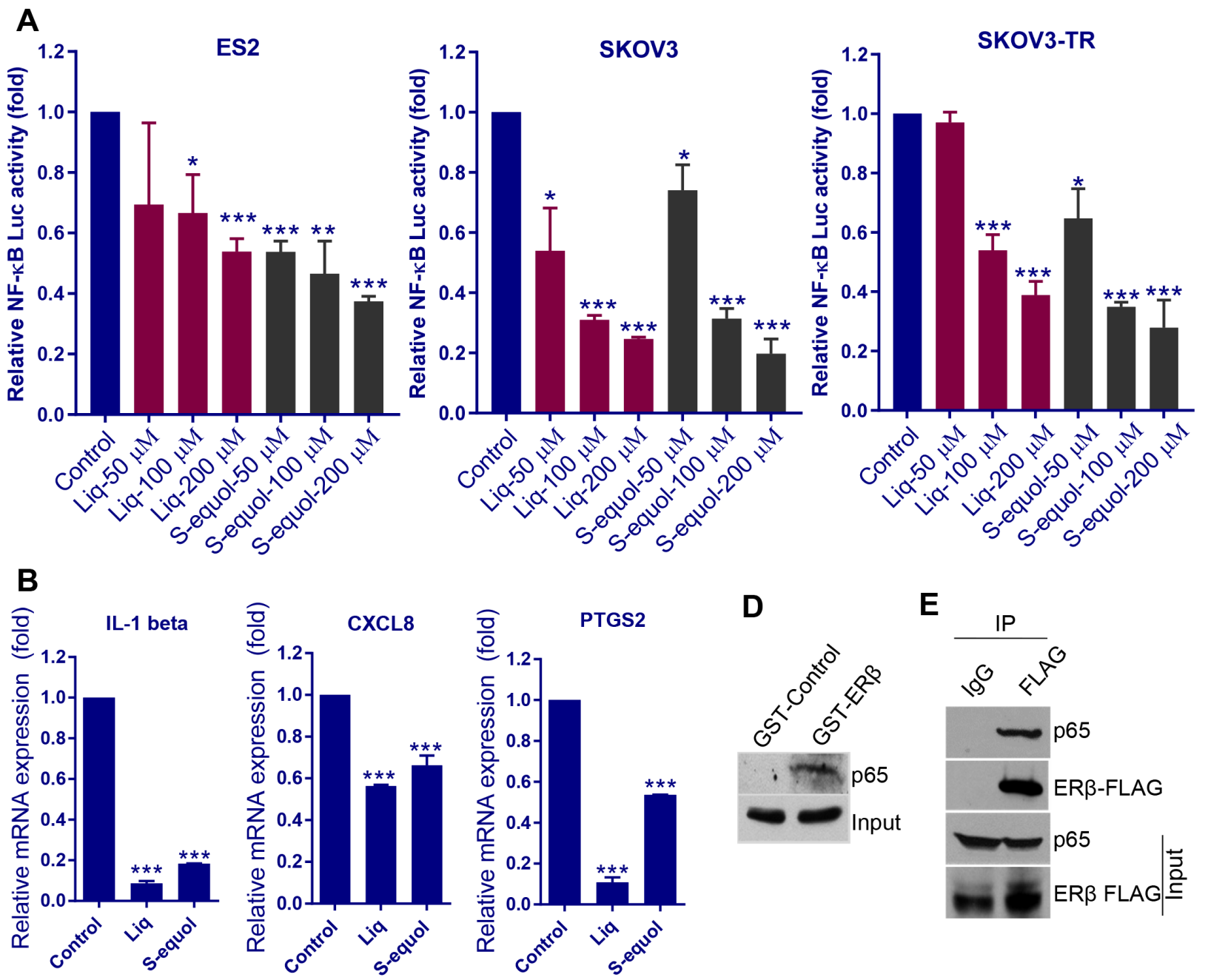

E
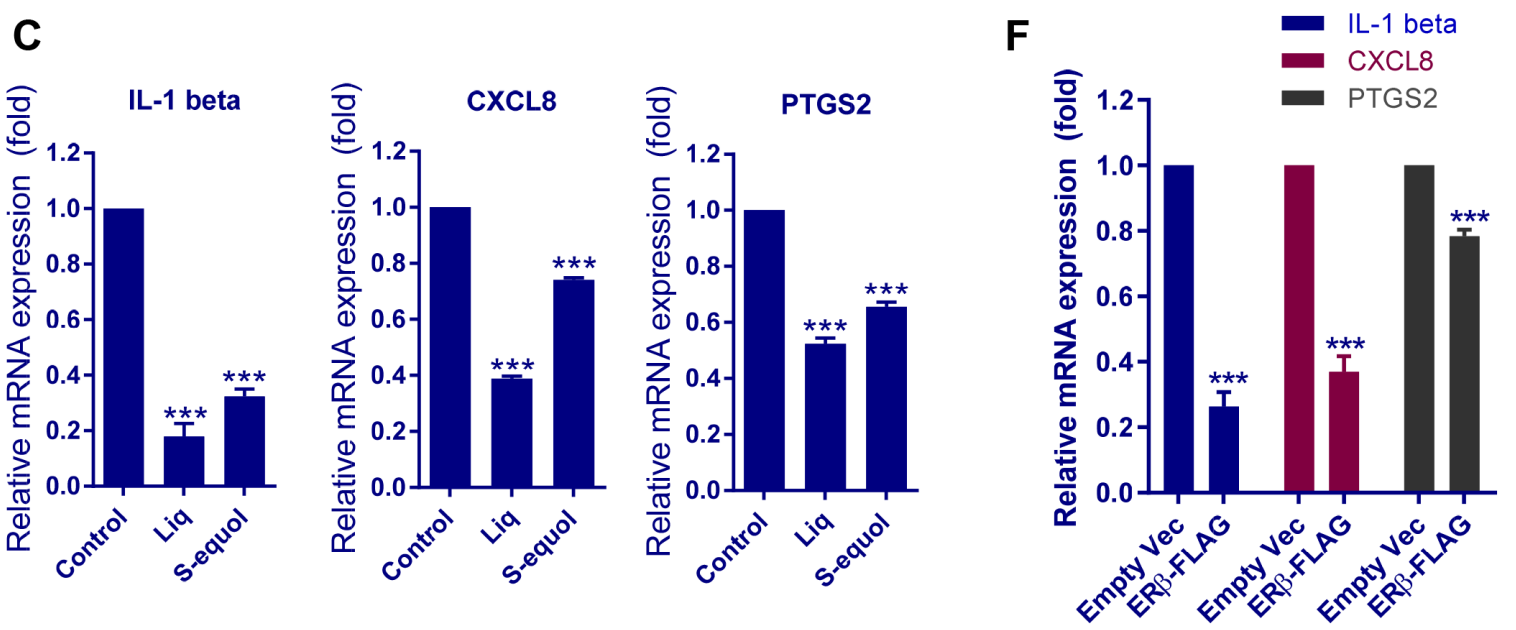

Figure 4: ERß agonists attenuate NF-кB pathway activation. (A) ES2, SKOV3, and SKOV3-TR cells were transfected with NF-kB-luc reporter plasmid and grown for $24 \mathrm{~h}$. Then, cells were treated with ER $\beta$ agonists and reporter activity was measured after $24 \mathrm{~h}$. ES2 (B) and SKOV3 (C) cells were treated with Liq or S-equol $(100 \mu \mathrm{M})$ for $24 \mathrm{~h}$, and the expression status of NF- $\mathrm{kB}$ target genes was analyzed by using RT-qPCR. (D) ES2 cell lysates were used in pull-down assays using GST or ER $\beta$-GST, and interaction of ER $\beta$ with p65 was analyzed by Western blotting. (E) ES2-ER $\beta$-FLAG cell lysates were subjected to immunoprecipitation with IgG or FLAG antibodies and the interaction of ER $\beta$ with $\mathrm{p} 65$ was confirmed by Western blotting. (F) SKOV3 cells were transduced with empty vector or ER $\beta$-FLAG expression vector and the expression of NF- $\mathrm{BB}$ target genes was analyzed by using RT-qPCR. Data are represented as mean $\pm \mathrm{SE}$. $* \mathrm{p}<0.05$; $* * \mathrm{p}<0.01 ; * * * \mathrm{p}<0.001$. 
cisplatin and paclitaxel treatment. Our results support the data from earlier studies that reported ER $\beta$ agonists function as anti-cancer agents [26]. Recent study suggested that the high potency of Liq is due to the ability of the ER $\beta$-Liq complex to recruit selective coactivators and its ability to bind to unique regulatory chromatin sites of estrogen-responsive genes [33]. Further, we provide evidence on the utility of Liq as a potential therapeutic agent using OCa Xenograft model.

Recent genomic studies suggested that ER $\alpha$ and ER $\beta$ have the potential to activate different sets of genes and that ER $\beta$ effects can be non-classical via its interactions with other transcription factors such as AP1, SP1, NF$\kappa \mathrm{B}$ and KLF5 [34, 35]. Global gene expression studies
A

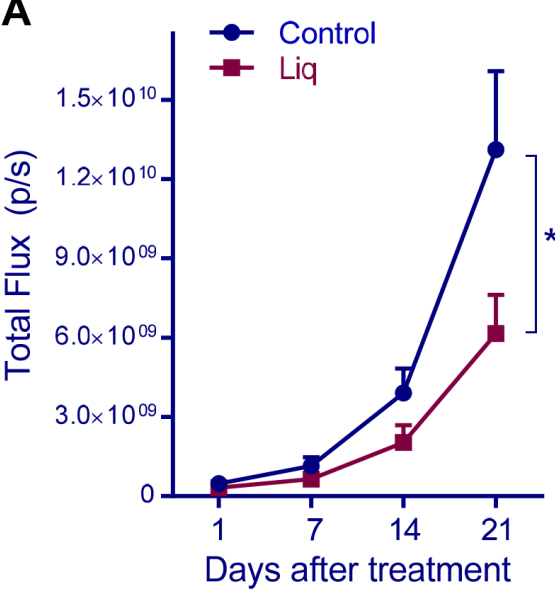

B

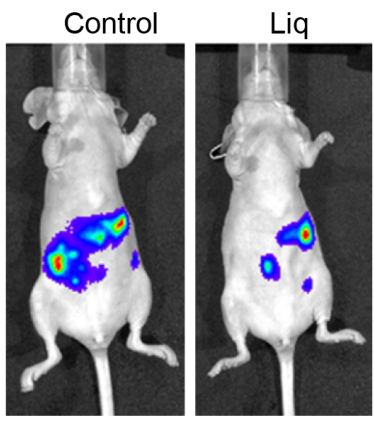

C

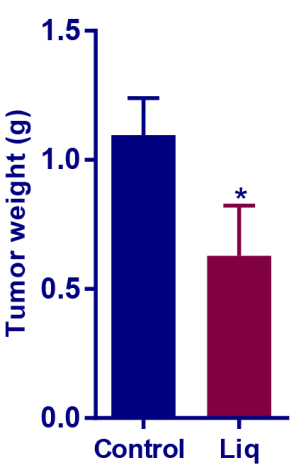

D

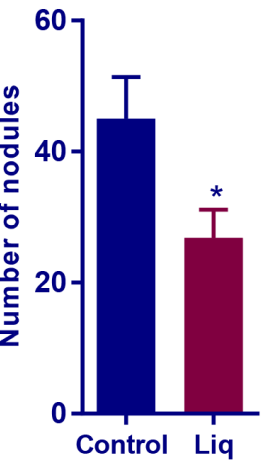

E
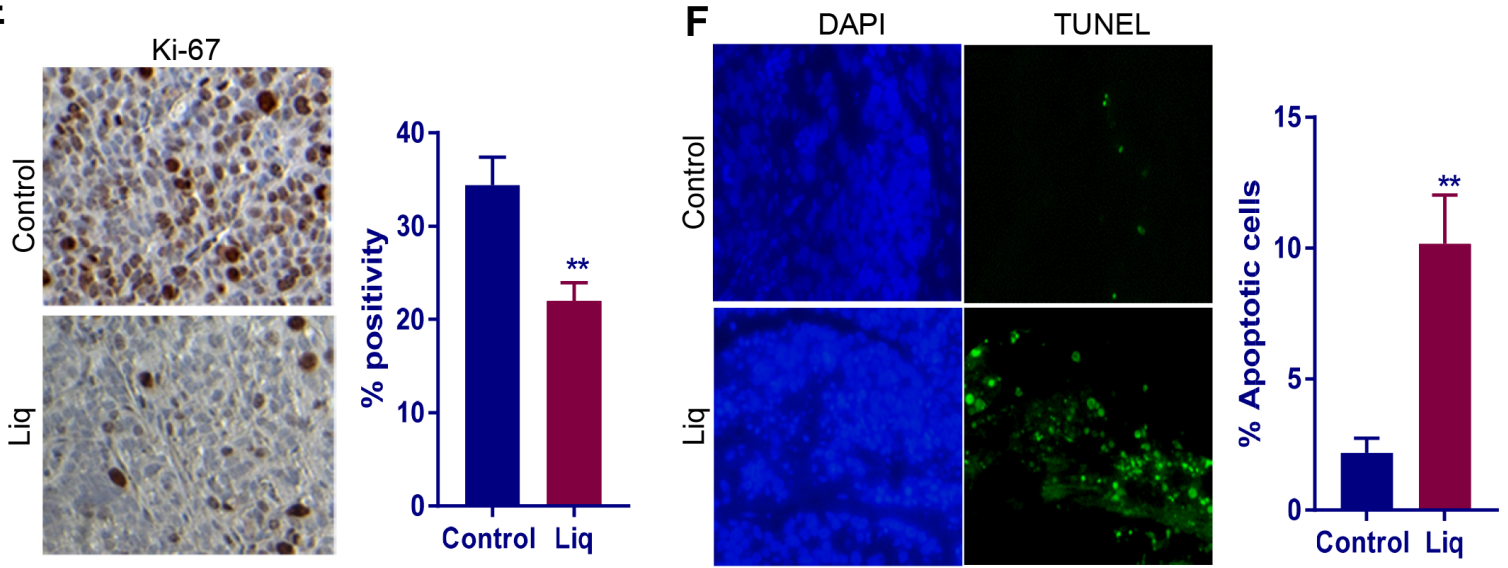

\section{G}
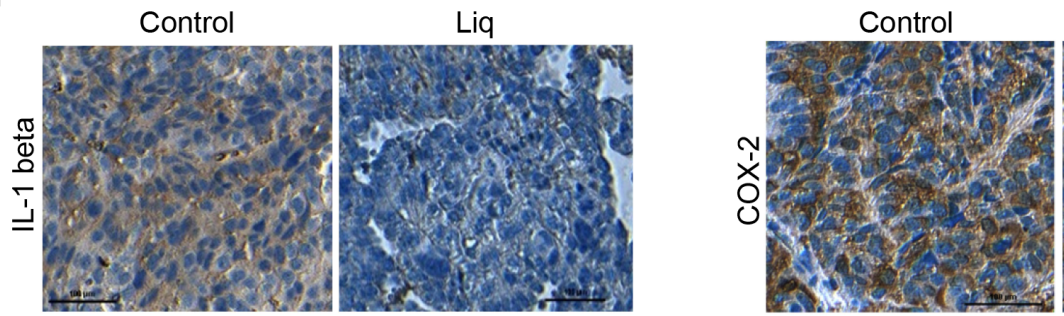

Liq

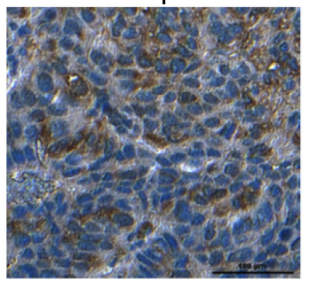

Figure 5: Effect of ERß agonist Liq on OCa progression in vivo. (A) Athymic nude mice were implanted with SKOV3ip1-Luc cells intra-peritoneally and treated with vehicle or Liq for 3 weeks. Luciferase intensity detected by the Xenogen in vivo imaging system was used to measure tumor growth. (B) Representative images of tumor-bearing mice from control and treatment groups are shown. The tumor weight (C) and number of nodules (D) from control and treatment group are shown. Ki67 expression (E) as a marker of proliferation and TUNEL staining (F) as a marker of apoptosis were analyzed by performing immunohistochemistry (IHC) on tumor sections. For quantitation, Ki-67-positive and apoptotic cells from five different fields were counted and plotted as histogram. Data are represented as

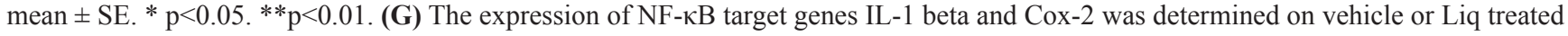
tumor sections by performing IHC. 
comparing estrogen and natural ER $\beta$ agonists revealed that natural ER $\beta$ agonists notably reduce the stimulation of genes promoting proliferation, and preferably induce genes that are more pro-apoptotic dependent on the status and ratio of ER subtypes present in a cell [36]. Our RNA-seq studies using OCa model cells confirmed these earlier observations and showed that ER $\beta$ natural agonists suppress cytokine, immune, and metastatic pathways and activate pathways that promote apoptosis.

Our RNA-seq analysis results found that majority of the top pathways modulated by Liq are related to inflammation. NF- $\kappa \mathrm{B}$ pathway is the key mediator of many of the inflammatory processes. Recent studies suggest that NF- $\kappa \mathrm{B}$ pathway plays essential roles in $\mathrm{OCa}$ initiation, progression, and its activation increases the aggressiveness of $\mathrm{OCa}[37,38]$. We found that treatment with Liq downregulated the expression of many genes involved in $\mathrm{NF}-\kappa \mathrm{B}$ pathway and negatively correlated with $N F-\kappa B$ signaling pathway and inflammation, further supporting the notion that Liq-mediated tumor suppression involves the attenuation of inflammatory pathways. NF$\kappa \mathrm{B}$ is known to regulate the expression of MMPs and is essential for the epithelial-mesenchymal transition and metastasis via modulation of MMPs [39, 40]. We found that Liq treatment suppresses the activation of MMPs. To corroborate these results, we examined the role of ER $\beta$ agonists in migration and invasion and found that both Liq and S-equol significantly reduced the migration and invasion of OCa cells.

ER $\beta$ exerts anti-inflammatory effects by repressing genes that promote inflammation, and ER $\beta$ signaling can cross-talk with $\mathrm{NF}-\kappa \mathrm{B}$ signaling pathway [7, 41-43]. Further, estrogens inhibit NF- $\mathrm{B}$ binding to the IL-6 promoter, and ER $\beta$-selective agonists inactivate microglia and invading $\mathrm{T}$ cells by downregulating the expression of NF- $\kappa \mathrm{B}[44,45]$. The synthetic ER $\beta$ agonist DPN inhibited nuclear translocation and phosphorylation of p65 by inhibiting I $\kappa \mathrm{B}$ degradation [46], and $\mathrm{ER} \beta$ functions as a gate-keeper for $\mathrm{NF}-\kappa \mathrm{B}$ signaling by repressing its expression and nuclear translocation [47]. Accordingly, in mechanistic studies using NF- $\kappa \mathrm{B}$ reporter assays, both $\mathrm{S}$-equol and Liq significantly reduced the reporter activity. Further, we confirmed the down regulation of $\mathrm{NF}-\kappa \mathrm{B}$ target genes upon treatment with S-equol and Liq. More importantly, our study demonstrated that ER $\beta$ specifically interacts with p65 subunit of NF- $\mathrm{KB}$ and overexpression of $\mathrm{ER} \beta$ reduced the expression of $\mathrm{NF}-\kappa \mathrm{B}$ target genes. Collectively, these findings suggest that natural ER $\beta$ agonists promote ER $\beta$ crosstalk with NF- $\kappa B$ and down regulate expression of NF- $\kappa \mathrm{B}$ target genes.

In summary, the results from this study established the potential of two natural ER $\beta$ agonists for treating OCa and provided evidence that natural ER $\beta$ agonists promote tumor suppression and anti-inflammatory pathways by modulating gene expression. Since S-equol and Liq are currently in clinical trials for other clinical indications and are well tolerated, identification of ER $\beta$ agonist therapy as a novel therapeutic for OCa may be readily transferred to clinical use with current chemotherapies.

\section{MATERIALS AND METHODS}

\section{Cell lines and reagents}

Human OCa cell lines ES2, SKOV3, and BG-1 were obtained from the American Type Culture Collection (ATCC) and were maintained as per ATCC guidelines. All the cells were passaged in the user's laboratory for fewer than 6 months after receipt or resuscitation. For ER $\beta$ agonist's treatment, OCa cells were maintained in phenol red-free RPMI medium containing 5\% dextran-charcoal treated FBS. S-equol was generously provided by Ausio Pharmaceuticals. Liquiritigenin (Liq) was purchased from Biopurify Phytochemicals (Chengdu, China). Paclitaxel was obtained from Tocris Bioscience (Bristol, UK). IL-1 beta, and p65 antibodies were purchased from Cell Signaling Technology (Beverly, MA), Cox-2 antibody was obtained from Santa Cruz Biotechnology (Dallas, TX) and FLAG antibody and Cisplatin were purchased from Sigma Chemical Co (St. Louis, MO). Turbofect transfection reagent and SuperScript III First Strand kit and luciferase lysis buffer were purchased from Thermo Scientific (Waltham, MA). In situ Cell Death Detection Kit was purchased from Roche (Indianapolis, IN). The Ki67 antibody was purchased from Abcam (Cambridge, MA). Stably ER $\beta$-expressing ES2 cells were generated by infecting them with pLenti6/V5-D-FLAG ER $\beta$ or empty control vectors and positive cells were selected with blasticidine $(5 \mu \mathrm{g} / \mathrm{mL})$. The specificity of ER $\beta$ agonists, antibodies and expression vectors were validated in our previous studies [26, 48, 49].

\section{Cell viability, clonogenic and caspase-3/7 activity assays}

The effect of ER $\beta$ agonists on OCa cell viability was assessed by using MTT assays. OCa cells were seeded in 96-well plates $\left(2 \times 10^{3}\right.$ cells/well $)$ and were treated with varying concentrations of S-equol or Liq for $72 \mathrm{~h}$. The MTT reagent was added to each well and incubated for $4 \mathrm{~h}$. Formazan crystals were solubilized in DMSO and the optical density was measured by using the micro-plate reader. The cell proliferation rates of control and ER $\beta$ overexpressing ES2 cells were measured using MTT assay. For combination studies, ES2 cells were seeded in 96 well plates $\left(1 \times 10^{3}\right.$ cells/well $)$ and after an overnight incubation, the cells were pretreated with vehicle or Liq $(25 \mu \mathrm{M})$ for $48 \mathrm{~h}$ followed by wash-off and replenished with varying concentrations of paclitaxel or cisplatin alone or in combination with Liq for 5 days. Cell viability was then measured using the MTT assay as described above. For the clonogenic assays, OCa cells (500 cells/ 
well) were seeded in 6-well plates and after an overnight incubation, cells were treated with S-equol or Liq for 72 h. The cells were washed with PBS and replenished with culture media and allowed to grow for an additional 7 days. The cells were then fixed in ice-cold methanol and stained with $0.5 \%$ crystal violet solution to visualize the colonies. Colonies that contain $\geq 50$ cells were counted. The effect of ER $\beta$ agonists on apoptosis was determined by using Caspase-3/7 activity assays. Briefly, $5 \times 10^{3}$ cells were seeded in 96 well plates and after overnight incubation, cells were treated with S-equol $(100 \mu \mathrm{M})$ or Liq $(100 \mu \mathrm{M})$ for $48 \mathrm{~h}$ and the Caspase-3/7 activities were determined according to manufacturer protocol (Promega, Madison, WI).

\section{Cell migration and invasion assays}

The cell migration and invasion were determined by using colorimetric QCM chemotaxis cell migration assay (EMD Millipore, Billerica MA) and the Corning ${ }^{\circledR}$ BioCoat ${ }^{\mathrm{TM}}$ Growth Factor Reduced Matrigel Invasion Chamber assay, respectively. ES2 and SKOV3 cells were pretreated with S-equol $(100 \mu \mathrm{M})$ or Liq $(100 \mu \mathrm{M})$ for $24 \mathrm{~h}$ and subjected to cell migration and invasion assays according to manufacturer protocols.

\section{RNA sequencing and qRT-PCR}

ES2 cells were treated with either vehicle or Liq $(100 \mu \mathrm{M})$ for $24 \mathrm{~h}$, and total RNA was isolated using RNAesy mini kit (Qiagen, Valencia, CA) according to the manufacturer's instructions. The purity of isolated RNA was determined by using Agilent 2100 BioAnalyzer. Illumina TruSeq RNA Sample preparation was performed following manufacturer's protocol, and the samples were run on an Illumina HiSeq 2000 (Illumina, Inc., San Diego, CA) in duplicates. RNA-sequencing was performed as described previously [50]. Differential expression analysis was performed by using DEseq, and significant genes with at least 1.5 -fold change with $\mathrm{p}<0.05$ were chosen for analysis. Using all significant and differentially expressed genes from the RNA-seq data, Ingenuity Pathway Analysis software (IPA) was used to interpret the biological pathways. To validate the selected genes, reverse transcription (RT) reactions were performed by using SuperScript III First-Strand kit, according to the manufacturer's protocol and real-time PCR was done using SYBR Green with the following primers: Actin: F-5'- GTGGGCATGGGTCAGAAG-3'; R-5'- TCCATCACGATGCCAGTG-3' CXCL8: F-5'ACTGAGAGTGATTGAGAGTGGAC-3'; R-5'-AACC CTCTGCCCCAGTTTTC-3'; MMP14: F-5'-CGAGGT GCCCTATGCCTAC-3'; R-5'-CTCGGCAGAGTCAAA GTGG-3'; MMP11: F-5'-CCGCAACCGACAGAAG AGG-3'; R-5'-ATCGCTCCATACCTTTAGGGC-3'; ICAM1: F-5'-ATGCCCAGACATCTGTGTCC-3'; R-5'-
GGGGTCTCTATGCCCAACAA-3'; VCAM1: F-5'-CAG TAAGGCAGGCTGTAAAA GA-3'; R-5'-TGGAGCTG GTAGACCCTCG-3'; MMP1: F-5'-CTCTGGAGTAAT GTCACACCTCT-3'; R-5'-TGTTGGTCCACCTTTCATC TTC-3'; PIK3CG: F-5'-GGCTACCATGAGCAGCTTA CC-3'; R-5'-CTGTGAGGTCGGTGTTCCG-3'; TNF: F-5'-CCTCTCTCTAATCAGCCCTCTG-3'; R-5'-GAGGA CCTGGGAGTAGATGAG-3'; MMP3: F-5'-TTCACTC AGCCAACACTG AA-3'; R-5'-ACAGCATCAAAGG ACAAAGC-3'; IL-1 beta: F-5'-AAGCTGAGGAAG ATGCTG-3'; R-5'-ATCTACACTCTCCAGCTG-3'; PTGS2: F-5'-CTGGCGCTCAGCCATACAG-3'; R-5'CGCACTTATACTGGTCAAATCCC-3'. Results were normalized to $\beta$-actin transcript levels, and the difference in fold expression was calculated using delta-delta-CT method.

\section{Reporter gene assays}

ES2, SKOV3, and SKOV3-TR cells were maintained in phenol red-free RPMI supplemented with $5 \%$ dextran coated charcoal-striped serum for $48 \mathrm{~h}$ prior to transfection. Cells were transiently transfected with

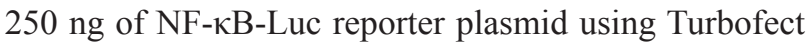
transfection reagent. After $24 \mathrm{~h}$, cells were treated with vehicle, S-equol, or Liq for additional $24 \mathrm{~h}$. Renilla reporter (50 ng) plasmid was co-transfected and used for data normalization. Cells were lysed in Luciferase Lysis Buffer, and the luciferase activity was measured by using the luciferase assay system (Promega, Madison, WI) in a luminometer.

\section{Immunoprecipitation and western blotting}

ES2 cell lysates were prepared using NP40/ TritonX100-lysis buffer $(50 \mathrm{mM}$ Tris $\cdot \mathrm{HCl}$ at $\mathrm{pH} 7.5$, $0.2 \%$ Triton X-100, 0.3\% Nonidet P-40, $150 \mathrm{mM} \mathrm{NaCl}$, $25 \mathrm{mM} \mathrm{NaF}, 0.1 \mathrm{mM}$ sodium orthovanadate) containing protease and phosphatase inhibitors. Cell lysates were immunoprecipitated with FLAG antibody, followed by Western blotting with p65 antibody. For GST pulldown assays, lysates were incubated with GST or ER $\beta$-GST fusion proteins, and bound proteins were isolated by GST-pull-down assay, and the interaction of ER $\beta$ with p65 was analyzed by Western blotting. Total proteins or IP complexes were mixed with $4 X$ SDS sample buffer and subjected to SDS-PAGE. Resolved proteins were then transferred onto nitrocellulose membranes and subjected to blocking with $5 \%$ non-fat dry milk powder for $1 \mathrm{~h}$ at room temperature and incubated with primary antibodies over night at $4^{\circ} \mathrm{C}$ followed by incubation with secondary antibody for $1 \mathrm{~h}$ at room temperature. Blots were developed using the ECL kit (Thermo Scientific, Waltham, MA). 


\section{Nude mice studies}

All animal experiments were performed after obtaining UTHSCSA IACUC approval, and all the methods were carried out in accordance with the IACUC-approved guidelines. SKOV3ip1 cells labelled with GFP-Luciferase $\left(1 \times 10^{6}\right.$ cells $)$ were injected intraperitoneally into 6-8 weeks old female athymic nude mice as described previously [51]. Tumor progression in mice was monitored by using Xenogen in vivo imaging system. Mice were randomly assigned into two groups ( $\mathrm{n}=5$ mice per group): (a) control $(30 \%$ Captisol) (b) Liq (20 mg/Kg body weight/day). The mice were monitored daily for adverse effects, and the treatment was continued for 3 weeks. At the end of the treatment, tumor weight, and the number of nodules were recorded. The tissue samples were fixed in formalin and processed for histological studies.

\section{Immunohistochemistry}

Immunohistochemical analysis was performed as described previously [26]. Tumor tissue sections were incubated in xylene and passed through series of graded alcohols followed by antigen retrieval using the antigen retrieval solution (Vector Labs, Burlingame, CA). Tissue sections were incubated in $3 \% \mathrm{H}_{2} \mathrm{O}_{2}$ solution for $20 \mathrm{~min}$ and then subjected to blocking using the Vector Lab Blocking Kit. Tissue sections were incubated overnight with primary antibodies of Ki-67 (1:100), Cox-2 (1:50), and IL-1 beta (1:100) and then with secondary antibodies. Immunoreactivity was visualized by using the DAB substrate and counterstained with hematoxylin (Vector Lab, Inc.). The proliferative index was calculated as percentage of Ki-67-positive cells in five randomly selected microscopic fields. TUNEL analysis was performed using the In situ Cell Death Detection Kit according to manufacturer's protocol and DAPI was used to visualize the nuclei. Percentage of apoptotic cells were calculated from five randomly selected microscopic fields in each group.

\section{Statistical analysis}

GraphPad Prism 6 software (GraphPad Software, SanDiego, CA) was used for all statistical analyses. A Student's t-test was used to assess statistical differences between control and Liq-treated groups. All the data represented in bar graphs are shown as means \pm SE. Statistical differences among groups were analyzed with ANOVA. $P$ value less than 0.05 was considered significant.

\section{CONFLICTS OF INTEREST}

The authors declare no conflicts of interest.

\section{FUNDING}

This study was supported by ThriveWell Cancer Foundation (159954) to GRS, NIH/NCI CA178499 and P30 CA054174-22 to RV, NIH/NCI CA164122-01 and CA179120 to MKR and CA209154 and CPRIT RP150055 to RL.

\section{REFERENCES}

1. Auersperg N, Wong AS, Choi KC, Kang SK, Leung PC. Ovarian surface epithelium: biology, endocrinology, and pathology. Endocr Rev. 2001; 22:255-288.

2. Petrillo M, Nero C, Amadio G, Gallo D, Fagotti A, Scambia G. Targeting the hallmarks of ovarian cancer: the big picture. Gynecol Oncol. 2016; 142:176-183.

3. Vaughan S, Coward JI, Bast RC Jr, Berchuck A, Berek JS, Brenton JD, Coukos G, Crum CC, Drapkin R, Etemadmoghadam D, Friedlander M, Gabra H, Kaye SB, et al. Rethinking ovarian cancer: recommendations for improving outcomes. Nat Rev Cancer. 2011; 11:719-725.

4. Dutta S, Wang FQ, Phalen A, Fishman DA. Biomarkers for ovarian cancer detection and therapy. Cancer Biol Ther. 2010; 9:668-677.

5. Grisham RN, Hyman DM, Iyer G. Targeted therapies for treatment of recurrent ovarian cancer. Clin Adv Hematol Oncol. 2014; 12:158-162.

6. Cunat S, Rabenoelina F, Daures JP, Katsaros D, Sasano H, Miller WR, Maudelonde T, Pujol P. Aromatase expression in ovarian epithelial cancers. J Steroid Biochem Mol Biol. 2005; 93:15-24.

7. Dey P, Barros RP, Warner M, Strom A, Gustafsson JA. Insight into the mechanisms of action of estrogen receptor $\beta$ in the breast, prostate, colon, and CNS. J Mol Endocrinol. 2013; 51:T61-74.

8. Nilsson S, Gustafsson JA. Estrogen receptors: therapies targeted to receptor subtypes. Clin Pharmacol Ther. 2011; 89:44-55.

9. Yuan B, Cheng L, Chiang HC, Xu X, Han Y, Su H, Wang L, Zhang B, Lin J, Li X, Xie X, Wang T, Tekmal RR, et al. A phosphotyrosine switch determines the antitumor activity of ER $\beta$. J Clin Invest. 2014; 124:3378-3390.

10. Chang EC, Charn TH, Park SH, Helferich WG, Komm B, Katzenellenbogen JA, Katzenellenbogen BS.Estrogen Receptors alpha and beta as determinants of gene expression: influence of ligand, dose, and chromatin binding. Mol Endocrinol. 2008; 22:1032-1043.

11. Warner M, Huang B, Gustafsson JA. Estrogen receptor $\beta$ as a pharmaceutical target. Trends Pharmacol Sci. 2017; 38:92-99.

12. Sareddy GR, Vadlamudi RK. Cancer therapy using natural ligands that target estrogen receptor beta. Chin J Nat Med. $2015 ; 13: 801-807$. 
13. Lo R, Matthews J. A new class of estrogen receptor betaselective activators. Mol Interv. 2010; 10:133-136.

14. Mersereau JE, Levy N, Staub RE, Baggett S, Zogovic T, Chow S, Ricke WA, Tagliaferri M, Cohen I, Bjeldanes LF, Leitman DC. Liquiritigenin is a plant-derived highly selective estrogen receptor beta agonist. Mol Cell Endocrinol. 2008; 283:49-57.

15. Jackson RL, Greiwe JS, Desai PB, Schwen RJ. Singledose and steady-state pharmacokinetic studies of S-equol, a potent nonhormonal, estrogen receptor $\beta$-agonist being developed for the treatment of menopausal symptoms. Menopause. 2011; 18:185-193.

16. Jackson RL, Greiwe JS, Schwen RJ. Emerging evidence of the health benefits of S-equol, an estrogen receptor $\beta$ agonist. Nutr Rev. 2011; 69:432-448.

17. Setchell KD, Clerici C, Lephart ED, Cole SJ, Heenan C, Castellani D, Wolfe BE, Nechemias-Zimmer L, Brown NM, Lund TD, Handa RJ, Heubi JE. S-equol, a potent ligand for estrogen receptor beta, is the exclusive enantiomeric form of the soy isoflavone metabolite produced by human intestinal bacterial flora. Am J Clin Nutr. 2005; 81:1072-1079.

18. Aso T, Uchiyama S, Matsumura Y, Taguchi M, Nozaki M, Takamatsu K, Ishizuka B, Kubota T, Mizunuma H, Ohta H. A natural S-equol supplement alleviates hot flushes and other menopausal symptoms in equol nonproducing postmenopausal Japanese women. J Womens Health (Larchmt). 2012; 21:92-100.

19. Aravantinos G, Pectasides D. Bevacizumab in combination with chemotherapy for the treatment of advanced ovarian cancer: a systematic review. J Ovarian Res. 2014; 7:57.

20. Brasseur K, Gevry N, Asselin E. Chemoresistance and targeted therapies in ovarian and endometrial cancers. Oncotarget. 2017; 8:4008-4042. doi: 10.18632/ oncotarget.14021.

21. Bossard C, Busson M, Vindrieux D, Gaudin F, Machelon V, Brigitte M, Jacquard C, Pillon A, Balaguer P, Balabanian $\mathrm{K}$, Lazennec G. Potential role of estrogen receptor beta as a tumor suppressor of epithelial ovarian cancer. PLoS One. 2012; 7:e44787.

22. Hoesel B, Schmid JA. The complexity of NF-kB signaling in inflammation and cancer. Mol Cancer. 2013; 12:86.

23. Treeck O, Pfeiler G, Mitter D, Lattrich C, Piendl G, Ortmann O. Estrogen receptor \{beta\} 1 exerts antitumoral effects on SK-OV-3 ovarian cancer cells. J Endocrinol. 2007; 193:421-433.

24. Paruthiyil S, Parmar H, Kerekatte V, Cunha GR, Firestone GL, Leitman DC. Estrogen receptor beta inhibits human breast cancer cell proliferation and tumor formation by causing a G2 cell cycle arrest. Cancer Res. 2004; 64:423-428.

25. Pinton G, Thomas W, Bellini P, Manente AG, Favoni RE, Harvey BJ, Mutti L, Moro L. Estrogen receptor beta exerts tumor repressive functions in human malignant pleural mesothelioma via EGFR inactivation and affects response to gefitinib. PLoS One. 2010; 5:e14110.

26. Sareddy GR, Nair BC, Gonugunta VK, Zhang QG, Brenner A, Brann DW, Tekmal RR, Vadlamudi RK. Therapeutic significance of estrogen receptor $\beta$ agonists in gliomas. Mol Cancer Ther. 2012; 11:1174-1182.

27. Simpkins F, Garcia-Soto A, Slingerland J. New insights on the role of hormonal therapy in ovarian cancer. Steroids. 2013; 78:530-537.

28. Palmieri C, Cheng GJ, Saji S, Zelada-Hedman M, Warri A, Weihua Z, Van NS, Wahlstrom T, Coombes RC, Warner M, Gustafsson JA. Estrogen receptor beta in breast cancer. Endocr Relat Cancer. 2002; 9:1-13.

29. Mak P, Leav I, Pursell B, Bae D, Yang X, Taglienti CA, Gouvin LM, Sharma VM, Mercurio AM. ERbeta impedes prostate cancer EMT by destabilizing HIF-1alpha and inhibiting VEGF-mediated snail nuclear localization: implications for Gleason grading. Cancer Cell. 2010; 17:319-332.

30. Konstantinopoulos PA, Kominea A, Vandoros G, Sykiotis GP, Andricopoulos P, Varakis I, Sotiropoulou-Bonikou G, Papavassiliou AG. Oestrogen receptor beta (ERbeta) is abundantly expressed in normal colonic mucosa, but declines in colon adenocarcinoma paralleling the tumour's dedifferentiation. Eur J Cancer. 2003; 39:1251-1258.

31. Rutherford T, Brown WD, Sapi E, Aschkenazi S, Munoz A, Mor G. Absence of estrogen receptor-beta expression in metastatic ovarian cancer. Obstet Gynecol. 2000; 96:417-421.

32. Halon A, Nowak-Markwitz E, Maciejczyk A, Pudelko M, Gansukh T, Gyorffy B, Donizy P, Murawa D, Matkowski R, Spaczynski M, Lage H, Surowiak P. Loss of estrogen receptor beta expression correlates with shorter overall survival and lack of clinical response to chemotherapy in ovarian cancer patients. Anticancer Res. 2011; 31:711-718.

33. Jiang Y, Gong P, Madak-Erdogan Z, Martin T, Jeyakumar M, Carlson K, Khan I, Smillie TJ, Chittiboyina AG, Rotte SC, Helferich WG, Katzenellenbogen JA, Katzenellenbogen BS. Mechanisms enforcing the estrogen receptor beta selectivity of botanical estrogens. FASEB J. 2013; 27:4406-4418.

34. Charn TH, Liu ET, Chang EC, Lee YK, Katzenellenbogen JA, Katzenellenbogen BS. Genome-wide dynamics of chromatin binding of estrogen receptors alpha and beta: mutual restriction and competitive site selection. Mol Endocrinol. 2010; 24:47-59.

35. Nakajima Y, Akaogi K, Suzuki T, Osakabe A, Yamaguchi C, Sunahara N, Ishida J, Kako K, Ogawa S, Fujimura T, Homma Y, Fukamizu A, Murayama A, et al. Estrogen regulates tumor growth through a nonclassical pathway that includes the transcription factors ERbeta and KLF5. Sci Signal. 2011; 4:ra22.

36. Gong P, Madak-Erdogan Z, Li J, Cheng J, Greenlief CM, Helferich W, Katzenellenbogen JA, Katzenellenbogen BS. Transcriptomic analysis identifies gene networks regulated 
by estrogen receptor $\alpha(\mathrm{ER} \alpha)$ and $\mathrm{ER} \beta$ that control distinct effects of different botanical estrogens. Nucl Recept Signal. 2014; $12: \mathrm{e} 001$.

37. Hernandez L, Hsu SC, Davidson B, Birrer MJ, Kohn EC, Annunziata CM. Activation of NF-kappaB signaling by inhibitor of NF-kappaB kinase beta increases aggressiveness of ovarian cancer. Cancer Res. 2010; 70:4005-4014.

38. Alvero AB. Recent insights into the role of NF-kappaB in ovarian carcinogenesis. Genome Med. 2010; 2:56.

39. Li YF, Xu XB, Chen XH, Wei G, He B, Wang JD. The nuclear factor-kappaB pathway is involved in matrix metalloproteinase-9 expression in RU486-induced endometrium breakdown in mice. Hum Reprod. 2012; 27:2096-2106.

40. Huber MA, Azoitei N, Baumann B, Grunert S, Sommer A, Pehamberger H, Kraut N, Beug H, Wirth T. NF-kappaB is essential for epithelial-mesenchymal transition and metastasis in a model of breast cancer progression. J Clin Invest. 2004; 114:569-581.

41. Cvoro A, Tatomer D, Tee MK, Zogovic T, Harris HA, Leitman DC. Selective estrogen receptor-beta agonists repress transcription of proinflammatory genes. J Immunol. 2008; 180:630-636.

42. Edvardsson K, Strom A, Jonsson P, Gustafsson JA, Williams C. Estrogen receptor beta induces antiinflammatory and antitumorigenic networks in colon cancer cells. Mol Endocrinol. 2011; 25:969-979.

43. Sun J, Ma X, Chen YX, Rayner K, Hibbert B, McNulty M, Dhaliwal B, Simard T, Ramirez D, O'Brien E. Attenuation of atherogenesis via the anti-inflammatory effects of the selective estrogen receptor beta modulator 8beta-VE2. J Cardiovasc Pharmacol. 2011; 58:399-405.

44. Chadwick CC1, Chippari S, Matelan E, Borges-Marcucci L, Eckert AM, Keith JC Jr, Albert LM, Leathurby Y, Harris HA, Bhat RA, Ashwell M, Trybulski E, Winneker RC, et al. Identification of pathway-selective estrogen receptor ligands that inhibit NF-kappaB transcriptional activity. Proc Natl Acad Sci U S A. 2005; 102:2543-2548.

45. Wu WF, Tan XJ, Dai YB, Krishnan V, Warner M, Gustafsson JA. Targeting estrogen receptor $\beta$ in microglia and T cells to treat experimental autoimmune encephalomyelitis. Proc Natl Acad Sci U S A. 2013; 110:3543-3548.

46. Huang SY, Xin H, Sun J, Li R, Zhang XM, Zhao D. Estrogen receptor $\beta$ agonist diarylpropionitrile inhibits lipopolysaccharide-induced regulated on activation normal $\mathrm{T}$ cell expressed and secreted (RANTES) production in macrophages by repressing nuclear factor $\mathrm{\kappa B}$ activation. Fertil Steril. 2013; 100:234-240.

47. Mak P, Li J, Samanta S, Mercurio AM. ER $\beta$ regulation of NF-kB activation in prostate cancer is mediated by HIF-1. Oncotarget. 2015; 6:40247-40254. doi: 10.18632/ oncotarget.5377.

48. Sareddy GR, Li X, Liu J, Viswanadhapalli S, Garcia L, Gruslova A, Cavazos D, Garcia M, Strom AM, Gustafsson JA, Tekmal RR, Brenner A, Vadlamudi RK. Selective estrogen receptor $\beta$ agonist LY500307 as a novel therapeutic agent for glioblastoma. Sci Rep. 2016; 6:24185.

49. Yuan B, Cheng L, Gupta K, Chiang HC, Gupta HB, Sareddy GR, Wang D, Lathrop K, Elledge R, Wang P, McHardy S, Vadlamudi R, Curiel TJ, et al. Tyrosine phosphorylation regulates ERbeta ubiquitination, protein turnover, and inhibition of breast cancer. Oncotarget. 2016; 7:4258542597. doi: 10.18632/oncotarget.10018.

50. Sareddy GR, Viswanadhapalli S, Surapaneni P, Suzuki T, Brenner A, Vadlamudi RK. Novel KDM1A inhibitors induce differentiation and apoptosis of glioma stem cells via unfolded protein response pathway. Oncogene. 2016; 36:2423-2434.

51. Chakravarty D, Roy SS, Babu CR, Dandamudi R, Curiel TJ, Vivas-Mejia P, Lopez-Berestein G, Sood AK, Vadlamudi RK. Therapeutic targeting of PELP1 prevents ovarian cancer growth and metastasis. Clin Cancer Res. 2011; 17:2250-2259. 